\title{
ANALYZING SOCIAL COHESION IN OPEN SPACES OF MULTIETHNIC POOR NEIGHBORHOODS: A GROUNDED THEORY STUDY
}

\author{
Marziyeh SALIMI ${ }^{1,}{ }^{*}$, Manouchehr FOROUTAN ${ }^{2}$, Asadollah NAGHDI ${ }^{3}$ \\ ${ }^{1}$ Young Researchers and Elite Club, Hamedan Branch, Islamic Azad University, Hamedan, Iran \\ 2 Department of Architecture, Hamedan Branch, Islamic Azad University, Hamedan, Iran \\ ${ }^{3}$ Faculty of Social Sciences and Economic, Bu-Ali Sina University, Hamadan, Iran
}

Received 01 December 2018; accepted 11 December 2018

\begin{abstract}
During the past two decades, economic crises and climate change have triggered mass migrations from rural areas to big cities and metropolises. Considering that the destination cities often lack the required capacity to systematically accommodate these newcomers, immigrants settle in unofficially on city margins. Since these immigrants have different ethnicities, the informal settlements constructed by them turn into multiethnic informal Settlements in which development of proper social ties becomes impeded. As a result, social cohesion is weakened and eventually ceases to exist among the residents in open community spaces. In this regard, the present study aims to analyze this process and the effects of multiethnicity on social cohesion in the open community spaces of poor urban areas and the role of environmental factors in this mechanism. The Hesar Imam Khomeini neighborhood, which is located in Hamadan Province and has a rural core, has given shelter to Lurish, Kurdish, Turkish and Persian-speaking immigrants during recent years, which makes it a suitable sample for study. Because of the existing limitations and in order to achieve the goal of the study, the grounded theory was used to conduct the research. In-depth interview was carried out on sixteen residents of the neighborhood, four individuals from each ethnicity. After coding the interviews using the theory, a grounded model of the study was formed. The results indicate that multiethnicity has negatively affected behavior settings, vibrancy and consequently social cohesion in the open community spaces of the area of study through the three factors of "different expectations from neighborhood space", "different time of attendance in open spaces" and "different residence size". It can be proposed that "creating spatial shared values" is one of the most effective strategies which can be used for narrowing gaps and increasing social cohesion in multiethnic neighborhoods.
\end{abstract}

Keywords: social cohesion, informal settlements, social capital, multiethnicity, open spaces, Hesar.

\section{Introduction}

The population of urban areas has reached that of rural ones for the first time during recent years (Egger, 2005, p. 2). According to the head of the United Nations Human Settlements Programme (UN-Habitat), 2007 was the first year in which half of the world population lived in urban areas. At the same time, the population in poor urban areas has exceeded one billion (UN-Habitat, 2006). The UN predicts that by 2030 more than 60 percent of the world population will live in urban areas and by 2017 the developing world will have an urban character rather than a rural one (United Nations, 2004). It is evident that migration from rural areas to poor urban districts is notably on the rise. A review of the findings of international organizations reveals growing concentrated poverty in cities and multiplication of slums in urban areas as an undeniable fact of urbanization during the $21^{\text {st }}$ century. In its 2003 report titled "The Challenge of Slums", the UN-Habitat agency introduces these urban areas as "a physical and spatial manifestation of urban poverty and intra-city inequality" (UN-Habitat, 2003, xxvi). Also, in its 2008 report titled "State of the World's Cities - Harmonious Cities", the agency states that more than one-third of urban populations live in slums (UN-Habitat, 2008). On the other hand, these informal settlements are the concentration place for different cultures and ethnicities. Climate change and consequently decline of farming are among the main reasons which have led to migration of different rural ethnicities to poor urban areas (Black et al., 2008; Khanian, Serpoush, \& Gheitarani, 2017).

${ }^{*}$ Corresponding author. E-mail: marziyeh.salimi67@gmail.com 
Various empirical studies have shown that racial and ethnic heterogeneities are associated with lower levels of support for welfare redistribution (Eger, 2010, p. 26). In fact, these social differences have resulted in social dissociation and this lack of cohesion is apt to create disagreements between social groups, individuals and systems and as a result the society may experience social exclusion (Van Tran, 2015). The negative effects of ethnic diversity on trust and willingness to engage in collective life have led to emergence of new concepts in the social cohesion literature (Putnam, 2000). Therefore, since slums are created by immigrants of various ethnicities, these informal settlements lack proper social cohesion, which is more evident in open and community spaces.

The concept of social cohesion entered policy debates of developed countries in the 1990s (Hulse \& Stone, 2007). But, social sciences have long been discussing the causes and effects of changes in social cohesion (Putnam, 2000). Social cohesion is recognized as the interrelationship between groups and organizations in a society (Stone \& Hughes, 2002). More than one century ago, Durkheim (1894) said that there was no clear definition for social cohesion at that time. Unfortunately, the problem still persists today. For example, Rosell's (1995, p. 78) definition of the concept, after being adjusted by Maxwell (1996), holds that social cohesion consists of building shared values and communities of interpretation, reducing disparities in wealth and income, and generally enabling people to have a sense that they are engaged in a common enterprise, facing shared challenges and that they are members of the same community (Rajulton, Ravanera, \& Beaujot, 2007). On the other hand, since social cohesion between various social groups is projected in space, it can be suggested that environmental sciences such as architecture, urban design and urban planning play a significant role in developing this concept. A report produced under the auspices of the American Planning Association indicated that any planning and designing procedure which ignores human behaviors and basic needs inevitably leads to formation of neighborhoods which fail at providing positive social ties for the inhabitants (Ziegler, 2007; Khanian, Bolouhar, Gheitarany, \& Nezhad, 2013).

As a result, in poor urban neighborhoods which house immigrants of various cultures, a social dissociation exists among the inhabitants. It is believed that efficient space design can increase social capital and create opportunities for social interaction and trust-building (Khanian, Marshall, Zakerhaghighi, Salimi, \& Naghdi, 2018). There is no doubt that human behavior is influenced by both social and physical factors. Social factors have always been given much attention, but physical factors seem to be in need of more study and understanding in order to contribute to better social interaction. The physical characteristics of urban neighborhoods play a significant role in social interactions. Therefore, patterns of neighborhood design can be produced for the purpose of reducing differences and creating a sense of belonging in the residents (Marzbali, Abdullah, Razak, \& Tilaki, 2014).
In this regard, the present study aims to analyze the effects of multicultural and multiethnic spaces on social cohesion by studying the behaviors and viewpoints of the inhabitants of urban multiethnic spaces via a spatial approach. The Hesar Imam Khomeini neighborhood in Hamadan Province was selected as a suitable case for study. The neighborhood has a rural core and was attached to the main urban area of the city by immigrants during the multicultural rural migrations of the 1980s and 1990s. This resulted in formation of a multicultural multiethnic poor neighborhood. It needs to be mentioned that some of the original inhabitants still live in the neighborhood today. The authors decided to include in the area of study open and community spaces, where ethnic diversity is highest. In this regard, a space was selected wherein four ethnicities, namely Lurish, Kurdish, Turkish and the natives (Persians) live. Considering that the subject of study is relatively new and there is no prominent theory which can be applied to the study, grounded theory was used to conduct the research.

With regard to the focus of this study on Iranian informal settlements, a review of the urbanization process in Iran indicates that formation of informal settlements or slums in this country began in 1941 with a slow pace (Hataminejad \& Zomorrodian, 2002; Naghdi, Khanian, \& Rueentan, 2016). However, economic and environmental changes alongside lack of proper urban and local management and planning led to expansion of slums as a large portion of the rural population flowed toward cities. Overall, the related statistics indicate that informal residence in Iran is an expanding phenomenon. This kind of settlement is currently considered a specific life-style and traces of it can be found in most Iranian cities (Hataminejad \& Zomorrodian, 2002). Lalehpour and Karbasi (2017) have categorized the reasons of formation of Iranian informal settlements based on the existing literature. Table 1 shows this categorization (Table 1).

\section{A review of social cohesion and its relation to space}

Social cohesion, similar to globalization, has become another buzz word of the day (J. Chan, To, \& E. Chan, 2006). Many have attempted to define and propose ways to measure social cohesion, and these different definitions and approaches use different indices (Dickes, Valentova, \& Borsenberger, 2010). Some perceive social cohesion as solidarity and trust and some others believe it to include such concepts as social inclusion, social capital and poverty (J. Chan, To, \& E. Chan, 2006). However, it seems that despite common usage, social cohesion has been misdefined, which has led to different researches having different interpretations of the concept (Jeannotte, 2003; Osberg, 2003). At the present, it is difficult to find a commonly accepted definition for social cohesion. Social cohesion is a very popular concept with academia and politicians. In 1996 the federal government of Canada created a social cohesion network which became one of the most active social 
cohesion research groups all around the globe (J. Chan, To, \& E. Chan, 2006). It can be proposed that the definition of social cohesion is a reflection of a person's mentality which projects itself in a particular behavior (J. Chan, To, \& E. Chan, 2006, p. 289). Chan et al.claim that social cohesion has three levels: micro, meso and macro. They suggest that different groups should have social communication and interaction at the meso-level so as to contribute to social cohesion. However, measuring social relations at the mesolevel has proven difficult (Dickes et al., 2010).

Nonetheless, increased social capital helps increase social cohesion. According to Putnam (2000, p. 19), social capital refers to the link between the community network and individual members as well as mutual benefits and trust which result from the link (Portes, 2014). Table 2 indicates the most common approaches to social cohesion as discussed by well-known theorists. As it is clear, the "social" aspect is present in all approaches.
Regarding the relationship between social cohesion and space, Shaw and McKay (1942) have reported that in urban communities and regions with high poverty rate and issues such as mental illnesses, high infant mortality rate, crimes and other forms of physical and social problems, social cohesion and interpersonal relationships are very weak (Almeida, Kawachi, Molnar, \& Subramanian, 2009). For this reason, many researchers establish a direct relationship between various neighborhood capitals such as social networks, social cohesion and healthcare (Berkman et al., 2004; Sampson, Morenoff, \& Gannon-Rowley, 2002; Whitley \& Mckenzie, 2005; Pearl, Braveman, \& Abrams, 2001). But, Sampson believes that not much attention has been given to finding out what factors contribute to establishment of social relations and social cohesion (Sampson et al., 2002). According to an influential work of Forrest and Kearns (2001), social cohesion comprises sharing norms and values, social solidarity, social control

Table 1. Reasons of formation of Iranian informal settlements (Lalehpour \& Karbasi, 2017)

\begin{tabular}{|c|c|c|c|}
\hline Researcher & $\begin{array}{l}\text { Year of } \\
\text { Study }\end{array}$ & Title of Study & Findings of Study \\
\hline Piran & 1998 & $\begin{array}{l}\text { Hasty and disharmonious urbanization: } \\
\text { inappropriate residence }\end{array}$ & $\begin{array}{l}\text { The informal market of lands and } \\
\text { accommodation as well as land separation } \\
\text { regulations }\end{array}$ \\
\hline Athari & 1992 & $\begin{array}{l}\text { Slums in cities and their impacts and } \\
\text { consequences }\end{array}$ & $\begin{array}{l}\text { Ignoring low-income groups in the urban } \\
\text { planning system }\end{array}$ \\
\hline Habibi & 1992 & $\begin{array}{l}\text { Transformation of villages adjacent to big cities } \\
\text { and their role in the accommodation system of } \\
\text { Iran }\end{array}$ & $\begin{array}{l}\text { Lack of enforceable bylaws for use of lands } \\
\text { outside city limits and territorial boundaries }\end{array}$ \\
\hline Rafiei & 1993 & Slums & $\begin{array}{l}\text { Shortages in the approaches of urban planning, } \\
\text { structural planning and housing }\end{array}$ \\
\hline Khatam & 1994 & $\begin{array}{l}\text { Housing plans and social categorization in } \\
\text { Tehran districts }\end{array}$ & $\begin{array}{l}\text { Lack of minimum separation standards in } \\
\text { comprehensive urban plans and ignoring the } \\
\text { needs of low-income groups }\end{array}$ \\
\hline Latifi & 1998 & $\begin{array}{l}\text { A socioeconomic analysis of Tehran slums } \\
\text { between } 1981 \text { and } 1993\end{array}$ & $\begin{array}{l}\text { Lack of nationwide executive planning followed } \\
\text { by urban, local and districtwide executive } \\
\text { planning }\end{array}$ \\
\hline Sarrafi & 2001 & $\begin{array}{l}\text { Toward a theory of organizing informal } \\
\text { settlements: from slums to urbanization }\end{array}$ & $\begin{array}{l}\text { Inequitable distribution of national wealth, lack } \\
\text { of district and local balances, shortcomings of } \\
\text { districtwide plans, lack of sufficient and proper } \\
\text { residential spaces for low-income groups in } \\
\text { structural plans }\end{array}$ \\
\hline Fanni \& Bashiri & 2010 & Informal land economy and informal settlement & $\begin{array}{l}\text { Shortcomings in housing policies for low- } \\
\text { income populations }\end{array}$ \\
\hline
\end{tabular}

Table 2. Different approaches to defining social cohesion

\begin{tabular}{|l|l|c|}
\hline \multicolumn{1}{|c|}{ Theorist } & \multicolumn{1}{c|}{ Type of Approach } & Year \\
\hline Rosell & (1) economic, (2) social & 1995 \\
\hline Bernard & (1) political, (2) social, (3) cultural, (4) economic & 1999 \\
\hline Berger-Schmitt, R. (2000) & (1) political, (2) social & 2000 \\
\hline Fernando Rajulton, Beaujot and Ravanera & $\begin{array}{l}\text { (1) political (voting and volunteering), (2) economic (job, income } \\
\text { and work force contribution), (3) social (social ties) }\end{array}$ & 2007 \\
\hline $\begin{array}{l}\text { Paul Dickes, Marie Valentova and Moni } \\
\text { Borsenberger }\end{array}$ & (1) political, (2) social, (3) cultural & 2010 \\
\hline
\end{tabular}


and a feeling of belonging to each other through a common identity and a strong bonding with the place where one lives.

Many attempts have been made to determine the different dimensions of social cohesion (O'Connor, 1998; Woolley, 1998). O'Connor (1998) introduces affiliation/ isolation, insertion/exclusion, participation/passivity and acceptance/rejection as the four main dimensions of social cohesion, which can be said to have a relationship with place (Dickes et al., 2010). The results of another study by Foster, Giles-Corti, and Knuiman (2010), which is based on the theory of new urbanism, encourages increased public presence in streets and higher walkability, which both can be interpreted as positive and meaningful relationships in social. It is believed that designing community spaces based on the idea of creating opportunities for establishing social interaction and trust can increase social capital, and in return increased social interaction contributes to higher social cohesion. Urban spatial design and planning makes it possible for a community to overcome the negative effects of criminal activities such as social exclusion and narrow the gap among its members who may come from different ethnic backgrounds ties (Marzbali et al., 2014). Creating social cohesion in a neighborhood requires establishment of various types of social capital, including social support, social leverage, informal social control, and neighborhood organization participation (Carpiano, 2006; Carpiano \& Kimbro, 2012). Considering that social cohesion has a bottom-up process, the quality of social integration at the neighborhood-level is the basis for creating social cohesion at higher levels (Forrest \& Kearns, 2001; Morrison, 2003). Taylor (1998) believes that even a small geographical unit can act as a behavior regulator and help the social ties inside a neighborhood and the behavioral patterns of the residents develop.

\section{Social cohesion in poor multiethnic neighborhoods}

During the last few decades, climate-induced and economic crises have forced a large number of villagers to migrate to cities (Black, Kniveton \& Schmidt-Verkerk, 2013). Often lack of appropriate urban infrastructures has resulted in these villagers settling in informally. This phenomenon is more evident in developing countries and has led to formation of slums at the margin of large cities throughout years (Durand-Lasserve \& Royston, 2012). Considering that most of these immigrants come from different cultures and ethnicities, no strong social cohesion exists in the open and community spaces of their neighborhoods. However, many researchers believe that strong social relations and mutual aid are characteristics of poor neighborhoods which help them fight poverty, unemployment and social exclusion (Forrest \& Kearns, 2001; Patel \& Kleinman, 2003). Despite this, different cultural and ethnic backgrounds of the residents make it difficult to ascertain the existence of social cohesion in open and community spaces in such neighborhoods. Some argue that economically deprived areas lack the elements which produce and sustain social ties and cohesion (Almeida et al., 2009). They draw on the social chaos theory and propose that poverty destroys positive social capital and procedures and as a result creates distrust and fear among residents (Moore \& Pinderhughes, 1993; Sampson, 2003; Sampson, Morenoff, \& Gannon-Rowley, 2002; Ross, Mirowsky, \& Pribesh, 2001). Establishing community spaces for social interactions in poor neighborhoods is expected to result in a wide range of positive outcomes, like social cohesion, social mobility opportunities, more social capital, better services, less crime, an improved neighborhood reputation, and more residential stability (Bolt, Van Kempen, \& Van Ham, 2008; Kleinhans, 2004; Tunstall \& Lupton, 2003).

Considering that the residents of such neighborhoods face multiple challenges in the quality of their lives, studying the methods which can help increase social cohesion among them can be very beneficial since positive social ties contribute to better physical and mental health and trustbuilding (Kawachi \& Berkman, 2000; Putnam, 2000). Putnam (2000) states that in communities with high levels of social interaction and social organization, residents enjoy more social cohesion (Portes, 2014). The aspects of social cohesion seem to reinforce one another; whenever people have, for example, the same ideas about life (shared norms and values), the chance of making social contacts is greater and so the feeling of being part of a certain group or a particular neighborhood or district is reinforced (Atkinson \& Kintrea, 2001). In her proposed method for measuring social capital, Berger-Schmitt (2000) says that social cohesion has two principal goal dimensions: (1) reducing disparities, inequalities and social exclusion within a society and (2) strengthening the social capital of a society. The second dimension includes all aspects which are considered a type of social capital. In communities which have more social cohesion, more investment might be made on general social infrastructures such as education, social welfare and healthcare services, which in return will decrease inequalities in accessing medical and healthcare services. Also, higher social cohesion produces more social support and mutual respect and prevents stress symptoms (Jen, Sund, Johnston, \& Jones, 2010; Pearce \& Smith, 2003). Considering that slums are formed without proper planning, they are spatially and structurally weak especially in open and community spaces. Studying the possible ways to correct the existing spaces in these informal settlements based on their multicultural and multiethnic nature has often been ignored by researchers. Doeksen (1997) proposes that the positive features of a constructed space can act as mediators for social feelings and sense of belonging. According to a theory by Mayo (1979), manipulation of a street can create a better social space in the neighborhood (Marzbali et al., 2014). Other studies also bespeak a meaningful relationship between the shape of streets and behavioral patterns (Hillier, 2004; Mason, 2010). Therefore, studying the passages and structures of open spaces in multiethnic poor neighborhoods can improve the outlook and 
decision-making of urban designers and planners. In the next section, these structures in the area of study have been analyzed using the grounded theory.

\section{Evaluating social cohesion from spatial perspective in the area of study using the grounded theory}

\subsection{Methodology}

Nowadays, qualitative research methods have earned their true place in science. One of the more successful qualitative methods is known as the grounded theory developed by sociologists Barney Glaser and Anselm Strauss. This theory relies on data collection, note-taking, coding, categorizing, describing and explaining. The origins of this theory can be traced back to symbolic interactionism and the works of Charles Horton Cooley and George Herbert Mead (Goulding, 1999). The grounded theory is usually used when no study has been conducted on the topic at hand and since no credible study has been conducted on lack of social cohesion in multiethnic slums, using this theory is justifiable. The analysis procedure consists of tagging concepts and elements with codes. The collected data are divided to smaller parts, conceptualized and then relinked to one another in a new way. Theoretical sampling in the grounded theory occurs based on the type of coding, and events which seem to be meaningful or indicative of concepts which can be used to acquire data are sampled. It can be said that the nature of the grounded theory consists of studying people in the social context using tools and methods which allow access to social meanings in a way that the researcher is directly present in the study field, talks to the subjects under study, reflects the reality from their viewpoint and provides a deep explanation of the reality under study (Creswell, 2009). Therefore, data collection and analysis have a mutual relationship. According to Strauss and Corbin (1990), research does not begin with a theory which is supposed to be substantiated; rather, research begins with a field of study and then what

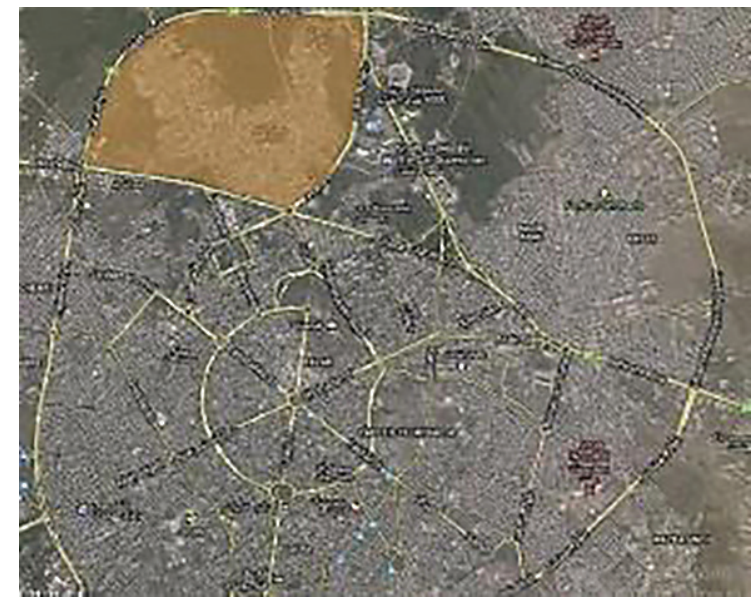

Figure 1. Geographical location of the area of study in Hamadan is suitable and related is allowed to unfold. In other words, unlike deductive methods which begin with a general theory and use hypotheses for experimental testing, the grounded theory is an inductive method which begins the research by direct observation and then forms patterns, implications or general categories and concepts. This does not mean that researchers who use the grounded theory do not have any hypothesis or presumption; rather, it means that what has been learnt beforehand forms a new study for shaping general principles and concepts; but, analysis is not performed to substantiate or reject hypotheses.

\subsection{Delimiting the immediate area of study}

One of the slums of Hamadan Province is "Hesar" district. Hesar is one of the poor neighborhoods of Hamadan which has a rural core. The neighborhood has and still is expanding over the farmlands of Hesar Village. The current state of Hesar indicates that uncontrolled constructions still happen in different parts of the neighborhood, especially on surrounding farmlands. Originally the village was known as "Hesar Piazkaran", but migration of a large number of the inhabitants and construction of residential units has led to the village becoming a section of the city (Urban Development and Renewal Company, 2004). Back in seventy years, around 200 families lived in the village but the village shrank in size as a result of mass migrations, and gradual constructions have led to a combined texture which is now known as Hesar. According to the 2011 statistical studies, Hesar has a population of 35,000 (Statistical Center of Iran, 2011; Zakerhaghighi, Khanian, \& Gheitarani, 2015; Kahvand, Gheitarani, Khanian, \& Ghadarjani, 2015).

In order for an accurate study of the district, a neighborhood was selected in Hesar Imam Khomeini Slum with maximum existing multiethnicity and social differences (Figures 1 and 2). Hesar Imam is located in north west of Hamedan leading to some agricultural and farming area. It is accessible from main city of Hamedan with urban streets. Also, The main study area is in the center of Hesar.

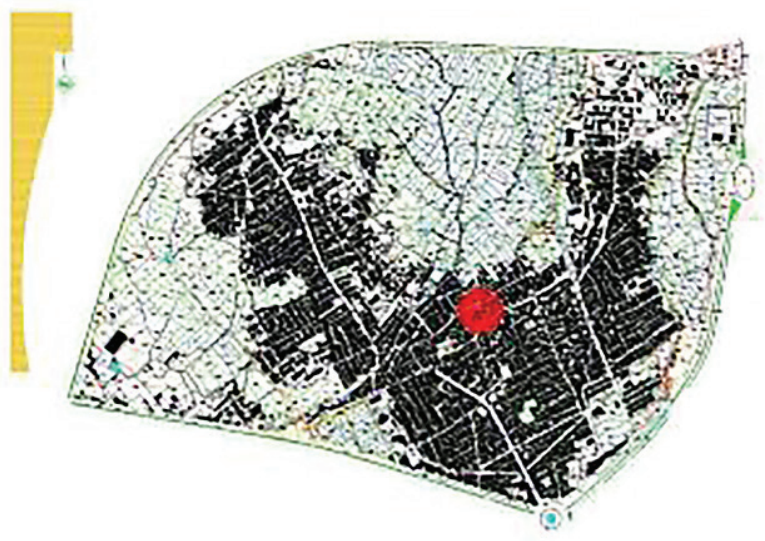

Figure 2. Map of the study area neighborhood structure 


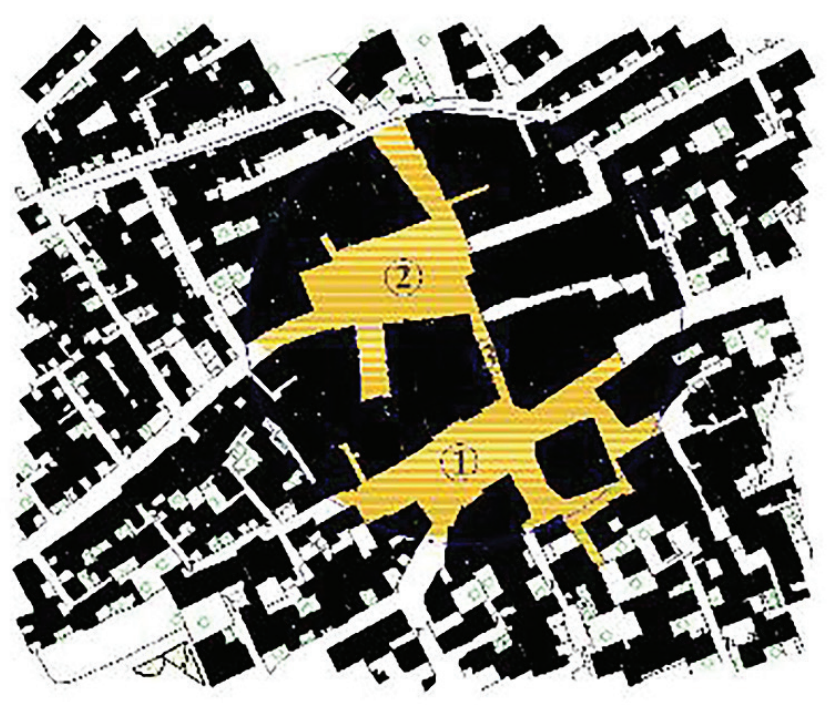

Figure 3. Geographical location of the rural core and the immigrants living quarters in the area of study

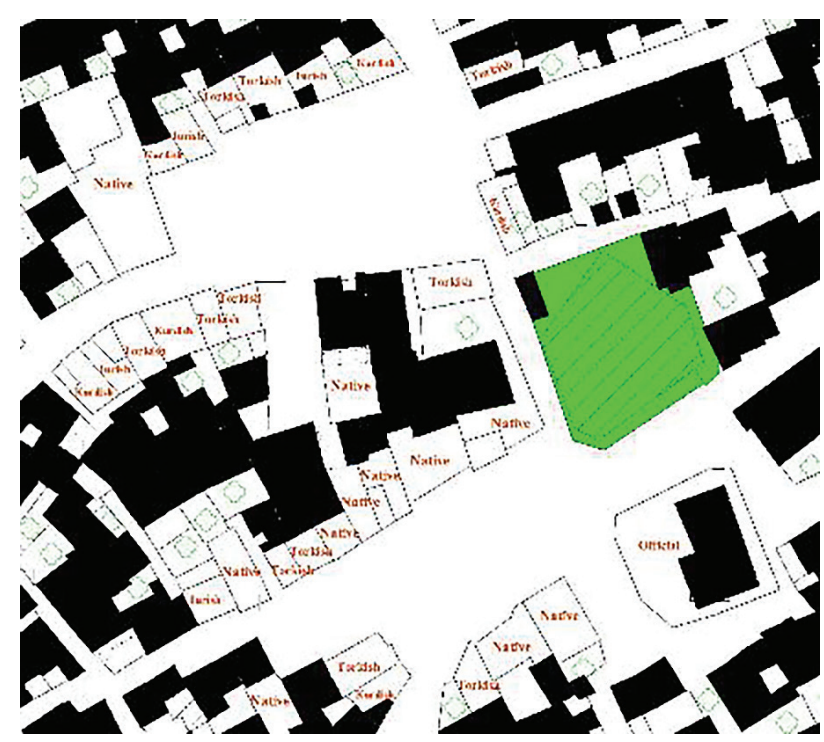

Figure 4. Area of study ethnicity map

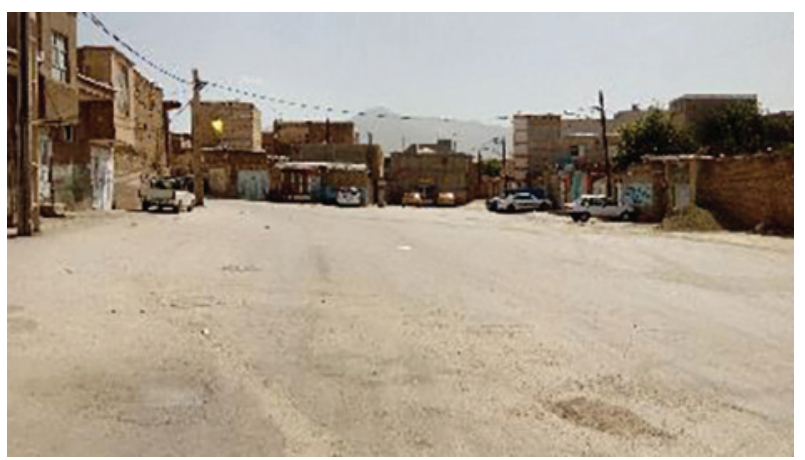

The area is the rural core of Hesar neighborhood which has come to direct contact with the living quarters of the immigrants. As it can be seen in Figure 3, section 1 is the rural core housing the native inhabitants; section 2 is an open space around which immigrants with different ethnic backgrounds live; and section 3 is a passage which connects sections 1 and 2. Imam Hassan Mojtaba Mosque (known as the old mosque) is located on the eastern wall of the passage. It needs to be mentioned that the mosque is used mostly by the native inhabitants, and the immigrants use another mosque located elsewhere in the neighborhood.

In order to analyze the social cohesion of this multiethnic neighborhood, the ethnicity of the residents dwelling in the immediate vicinity of the selected area was determined. Figure 4 shows the results.

The majority of the residents consist of four ethnicities: Lurish, Kurdish, Turkish and the natives (Persians). A number of pictures taken of the area of study and its open and community spaces can be seen in Figure 5 .

In-depth interview was carried out on 16 residents of the neighborhood - four members from each ethnicity. The grounded theory methodology was executed in the following stages:

Overall, data collection, note taking, coding and memoing were performed $a b$ initio. Sorting was performed only when all categories were saturated, after which drafting the write-up became possible. Then coding was performed, during which the collected data were reduced to separate meaningful units and then became conceptualized. Coding was performed in three stages of open coding, axial coding and selective coding based on Strauss's theory (1990). During open coding, the collected data were reduced, analyzed, compared, tagged and conceptualized. During axial coding, the formed categories were linked and their relations were analyzed. During selective coding, one category was selected as the central category to relate all categories together. The sample size in this type of sampling method, which is exclusively used in qualitative field studies, depends on the theoretical saturation of the study question. Therefore, interviews continued until no new information could be extracted from the collected data.

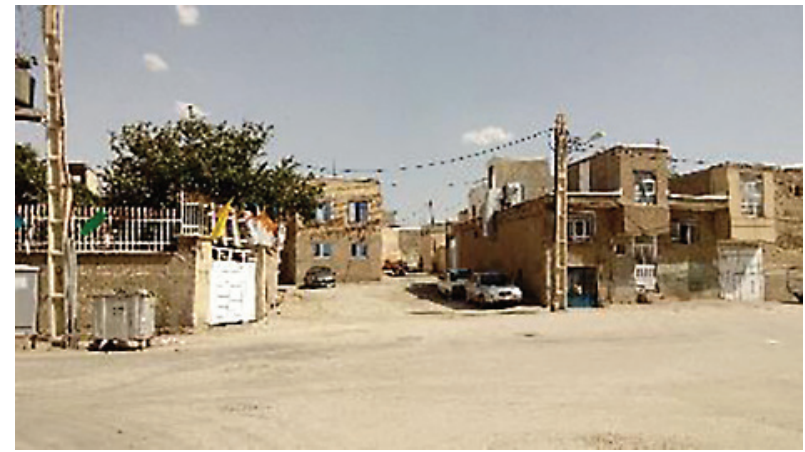

Figure 5. Pictures taken of the area of study 


\section{Categories extracted based on the condition of social cohesion in the area of study}

\section{Different expectations from neighborhood space}

During the interviews, participants had different expectations from the neighborhood space. It became clear that each participant goes to the neighborhood space for a particular reason and then leaves the area after performing his/her daily affairs. In-depth analysis of the extracted codes from the interviews indicated that the residents have different mental images of the neighborhood, spaces outside their houses and various passages inside the area. Since the mental image of any person is formed by his/ her expectations from an object, it can be inferred that different mental images of the space under study has resulted in a significant reduction of social cohesion. Hamid, a 34-year-old native of the neighborhood with a relatively favorable economic condition, says: "The space in front of the mosque is like a home to me and I earn my daily bread mostly there. And I always meet friends and neighbors in that area and my son Abbas also plays there." Ali, a 40-year-old resident who migrated to the neighborhood five years ago, says: "When every evening I return home from the workshop in which I work, I buy whatever I need from the city center; when I get home I don't leave until the next morning when I go to work." Also, Figure 6 shows an old woman with traditional Kurdish clothes illustrating a different personal viewpoint to the place.

\section{Different time of attendance in open spaces}

Another factor which was prominent in the interviews was the residents' different time of attendance in the space under study. Central codes extracted from the interviews indicated that the main reason for this difference was the different lifestyle of each resident, which is rooted in his/her ethnic and cultural background. Nahid, a 28 year old Kurdish resident who has recently joined the neighborhood, says: "We are used to having dinner late, and naturally before dinner my husband and children are out in the neighborhood space. We

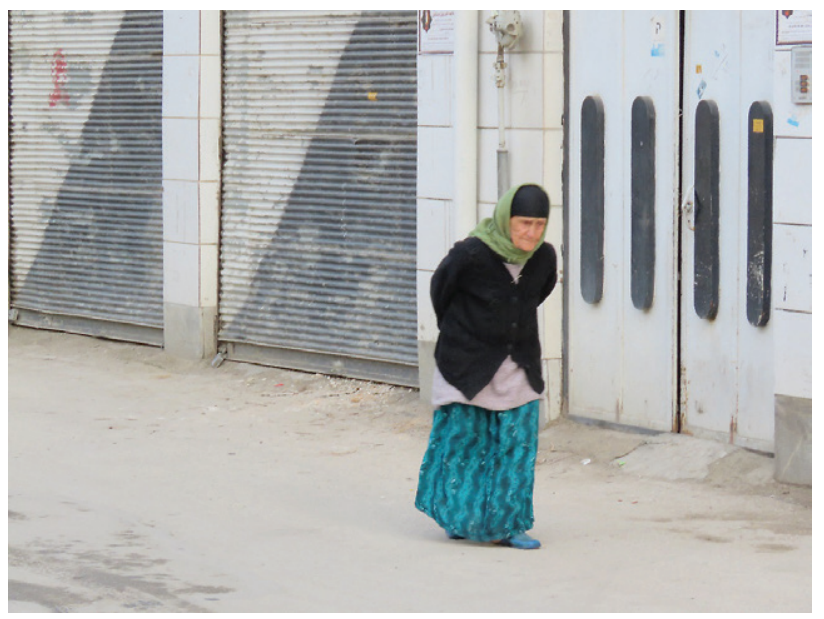

Figure 6. An old woman with traditional Kurdish clothes in the study area (Authors, 2018) also get up late in the morning and they are home then." Akram, a 34 year old Turkish longtime resident, on the other hand says: "My husband gets up early in the morning. I also go the bakery in the early morning and do my daily shopping. Then I do the household chores. Sometimes I don't see my neighbors for quite a few days." The economic condition of the residents can also have certain effects on their different time of attendance in the neighborhood space. In fact, one of the defining characteristics of these neighborhoods is the variety of the residents' jobs.

\section{Different residence size}

Some non-native interviewees said that because of the small size of their houses, they have to do certain chores in the open space in front of their abodes. But, the native residents said that they do all their household chores inside their houses and were unwilling to use the open space for this purpose. Reza, a 45-year-old Lurish resident, says: "Our entire house is 55 square meters. In the last year housecleaning, we had to dust and wash our rugs in the public space in front of the house; Ahmad and his family, who come from the same village I do and live in the next alley, helped us with the cleaning." This is highlighted in Figure 7 which two house on the study are are significantly different in terms of size.

\section{Detached behavior settings}

In the evening and before noon small social interactions occur in the form of 2-3 people gatherings in the area of study. These interactions are usually far from each other and occur out of public sight. Codes extracted from the interviews indicate that the residents typically commune with their close friends and fellows, who are few in number but similar in lifestyle. They gather around in one another's houses in intimate get-togethers and soirees. Hussein-Ali, a 60 year old Kurdish retired resident who has been living in the neighborhood since 10 years ago when he migrated to the area, says that he usually kills time in a park behind the neighborhood. Since there

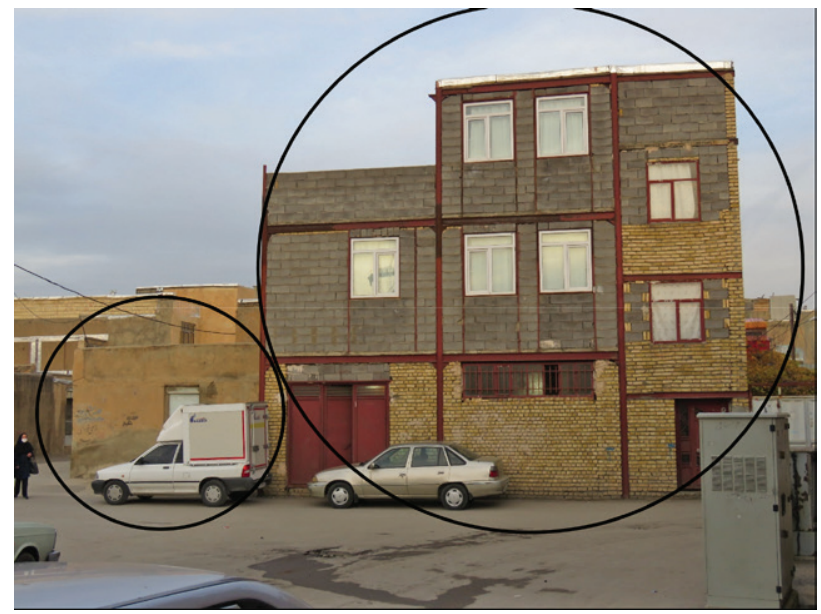

Figure 7. Two houses next to each others with significant different scales (Authors, 2018) 
are no Kurdish people in the immediate space in front of his house, Hussein-Ali rarely spends time there unless he catches sight of Ghasem, a 57 year old Kurdish resident, in the alley in which case they spend some time together under the awning in front of his house. It seems that cultural and ethnic differences and consequently different lifestyles prevent formation of cohesive and linked behavior settings despite available open spaces with favorable capacities.

\section{Weak vibrancy}

Certain codes extracted from the interviews indicated that "lack of vibrancy" is another feature of the space under study, which has affected social cohesion in the area. A review of the concept of vibrancy helps us better understand the extracted codes. In Creating a Vibrant City Center: Urban Design and Regeneration Principles, Paumier (2007, pp. 69-73) says that a successful public space should be able to admit a large number of individuals, as well as nearby retail centers in order to encourage and produce walkability and pedestrian activity. Jacobs (1961) introduces four principles to create productive variety in urban streets and areas and increase urban vibrancy: (1) the area should serve more than one primary function; preferably more than two; (2) blocks must be short to allow pedestrians to turn corners and enter new streets frequently; (3) buildings need to vary in age, condition and economic yield; (4) density should be enough to meet the needs of the people there but not greater. Jacobs emphasizes functional variety in the first principle, physical variety in the second and third principles and activity variety in the fourth principle. Jacobs believe that variety results in vibrancy (Khastou \& Rezvani 2010, p. 2). Therefore, another factor that contributes to urban vibrancy is functional, physical and activity variety. According to Ian Gehl (1996), in vibrant areas "optional" and "social" activities occur in a relatively large timespan. With regard to these principles, it can be suggested that vibrancy is weak in the area of study. Morteza, a 17 year old student, says: "I have no motivation to spend time in the open spaces of the neighborhood, since there is no place with shades or anywhere I can have fun with my friends. I usually go to the city with my classmates and friends to kill time." Overall, from the viewpoint of the inhabitants no functional, physical or activity variety exists in the neighborhood.

As it is clear in Figure 8, there is no activity and interaction in main small park of the study area. To be more specific, this space is not able to create vitality.

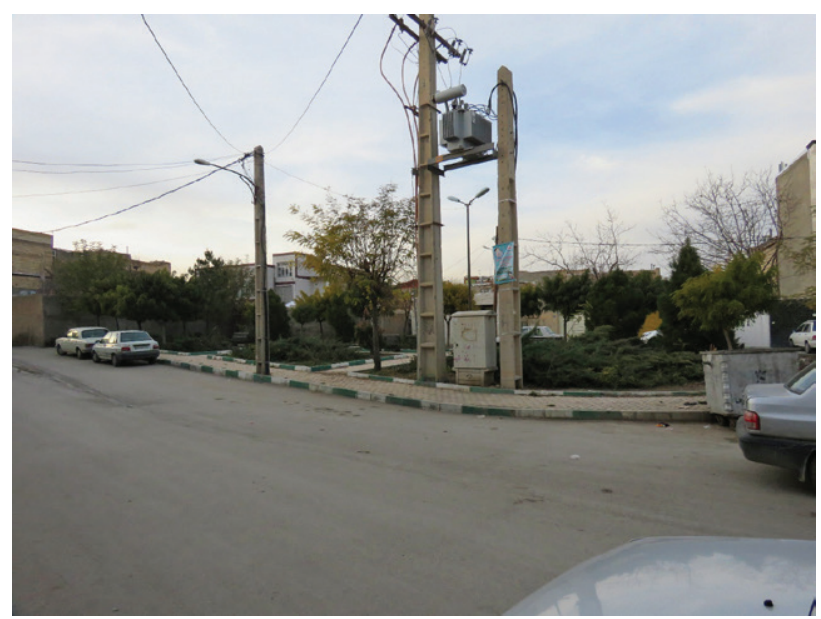

Figure 8. Main small park in the study are with no significant activity and vitality in it a sunny day (Authors, 2018)

\section{Lack of social capital}

Regardless of the price and physical properties of their houses such as accessibility, the interviewees unanimously believed that living in another house in the neighborhood would make no difference for them. This indicates a type of disappointment in their place of living. Open and axial codes extracted from the interviews revealed that the space under study has weak social capital. In other words, after years of expansion during which the physical structure of the neighborhood has been shaped, the inhabitants have not become socially intimate, and as a result social cohesion is lacking. Mohsen, a 45 year old native of the neighborhood, says in nostalgia: "When a lot of the neighborhood original people moved out and were replaced by immigrants, the neighborhood and the space in front of the old mosque [Imam Hassan Mojtaba Mosuqe] are no longer like before; I don't feel familiar with the area anymore."

\section{Relating extracted categories and forming A Grounded Theory of social cohesion in the multiethnic area of study}

Extracted categories indicate that the "different lifestyle" category covers all perceptions of the neighborhood residents as indicated in Table 3.

Finding a central category allowed for forming a grounded theory on the subject under study. The conse-

Table 3. Extracted categories and the central category

\begin{tabular}{|l|l|l|c|}
\hline \multicolumn{1}{|c|}{ No. } & \multicolumn{1}{|c|}{ Category } & \multicolumn{1}{c|}{ Type of Category } & Central Category \\
\hline 1 & Different Expectations from Neighborhood Space & Conditional & Different lifestyle \\
\hline 2 & Different Time of Attendance in Open Spaces & Conditional & \\
\hline 3 & Different Residence Size & Conditional & \\
\hline 4 & Detached Behavior Settings & Interactional & \\
\hline 5 & Weak Vibrancy & Interactional & \\
\hline 6 & Lack of Social Capital & consequential & \\
\hline
\end{tabular}


quence of the central category, i.e. "different lifestyle" which itself has been extracted from the other categories, is "lack of social capital" which has led to weak social cohesion in the area of study. It can be proposed that "weak social cohesion" is the consequence of the two the interactional categories "detached behavior settings" and "weak vibrancy". These two interactional categories result from the three categories "Different Expectations from Neighborhood Space," "Different Time of Attendance in Open Spaces" and "Different Residence Size". Finally, the root of all categories is "racial, ethnic and cultural" differences between the immigrants on the one hand and between the immigrants and the native residents on the other hand (Figure 9).

This study was conducted out of the necessity of analyzing the effects of multiethnic spaces on social cohesion in poor urban neighborhoods, which are majorly formed by immigrants. Having reviewed the existing literature about slums and social cohesion, the authors decided to choose the grounded theory as a suitable methodology for the study. After interviewing sixteen neighborhood residents, open, axial and selective codes were extracted. Then the "conditional", "interactional" and "consequential" categories and the central category were formed based on which a grounded model was proposed.

The principal effect of multiethnic spaces on social cohesion is "formation of different lifestyles". This is intensified by unplanned informal construction and design. In fact, this unplanned informal construction and design not only fails to induce behavioral changes but also widens the social gap between the residents. In light of this, proper construction and design polices for creating social cohesion and narrowing social gaps using the proposed grounded model herein will be discussed below.

\section{Discussion and conclusions}

During the last decade, climate-induced crises and critical economic conditions all around the globe, especially in developing countries, have resulted in mass migrations from small towns and villages to big cities and metropolises with more favorable economic conditions and more job opportunities. But, lack of proper urban and physical infrastructures which can accommodate this phenomenon has led to formation of slums and poor neighborhoods on the margin of cities. A careful study of these informal settlements indicates that because of the inhabitants' ethnic diversity and consequently the multicultural nature of the settlements, cohesive social ties do not get established among the inhabitants, and as a result social cohesion is challenged in these areas. This problem becomes more tangible when a multiethnic poor neighborhood has a rural core, and as a result differences come to the fore between immigrants with different ethnic backgrounds on the one hand and between those immigrants and native residents on the other hand. In this regard, the present study focused on analyzing social cohesion in multiethnic poor neighborhoods. After reviewing the concepts which are related to social cohesion and poor multiethnic slums, the suitable methodology was selected. Considering that no proper conceptual model exists in the related literature, the grounded theory was chosen to conduct the study in the sample area. The area of study is an open community space in a poor neighborhood located in Hamadan Province, which has a rural core and houses both immigrants with different ethnic backgrounds and native residents. From each of the four ethnic groups in the neighborhood, namely Lurs, Kurds, Turks and the natives who speak Persian, four people were selected and a total of 16 people were interviewed with the open and in-depth method. The results were analyzed at different stages and a grounded model was formed.

In validation of the proposed grounded model, it was revealed that it has certain similarities with Forrest and Kearns' (2001) study on the formation of social cohesion in open community spaces of neighborhoods. Forrest and Kearns suggest that there is a direct relationship between social capital and social cohesion in the community spaces of neighborhoods and neighborhood units. The present

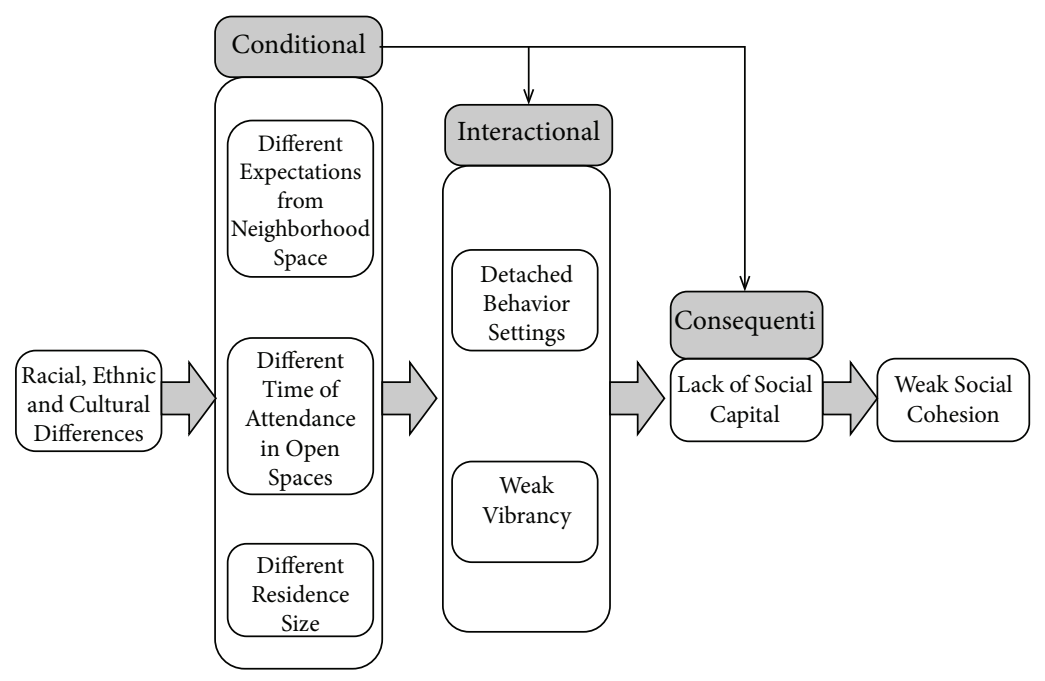

Figure 9. Grounded model of social cohesion in the area of study 
study also indicates that social capital is a consequential phenomenon negatively affected by racial, ethnic and cultural differences, which eventually leads to weak social cohesion.

Echeverría, Diez-Roux, Shea, Borrell, and Jackson (2008) found out that social cohesion is weak in multiethnic community spaces, which results in more depression and less willingness in the residents to appear in such spaces. Their findings are in conformity with the "conditional" category of the present study, since it was revealed that the two interactional categories of "linked behavior settings" and "vibrancy", which contribute a lot to the residents' mental health, are missing in the area of study.

A review of non-Iranian studies corroborates the general findings of the mentioned researches. Abramo (2016), for example, concluded in his study about informal settlements in Latin American cities that development of informal markets in such settlements set up by the residents has -owing to an increase of social capital- boosted social interactions between the dwellers who have migrated to those settlements from different locations. Abramo argues that daily economic needs fulfilled in places such as local markets are among the factors which contribute to formation of shared interests and values and which counter the impact of cultural differences. In his study about the informal settlements of Moctezuma in Mexico from the "placemaking" viewpoint, Lombard (2014) suggests that social and spatial processes go hand in hand in construction of informal settlements as places with lived experience. $\mathrm{He}$ concludes that society and space are interdependent in Moctezuma informal settlements.

The findings of the study confirm that racial, ethnic and cultural differences lead to formation of the central category of "different lifestyle", and when this category becomes manifest in a multiethnic area, it leads to smaller-scale categories such as "different expectations from the neighborhood space" and "different time of attendance in open spaces" which in turn lead to "conditional" and "consequential" categories and eventually weaken social cohesion in the area. Another point which needs to be mentioned is that since the various spaces of the neighborhood under study have not been constructed based on proper planning and designing and lack the required infrastructures to fulfill the needs of the residents, they play no part in increasing social cohesion in the area. Considering the weakness of social cohesion mechanism in the area of study, any new construction and landscaping carried out as an architecture and designing strategy should be oriented toward narrowing the gap resulting from cultural differences and emphasizing the shared values and activities of the residents. Focusing on the function of the old mosque (Islam is the shared religion of all four ethnicities) as a sacred place for all of the neighborhood residents, or commercial activities and daily shopping as well as proper urban furniture can be considered as examples of effective policies for creating shared values and activities among the residents. The model presented below indicates this.

This model emphasizes the necessity of social participation of residents with regard to their shared interests and values. In their study about the informal settlements of Alexandria, Nassar and Elsayad (2017) found out that spatial interventions aiming at increasing the social participation of the slum dwellers have notably contributed to stabilization of these settlements. With all this in mind, it can be said that spatial factors need to be implemented in a manner that help increase social participation among the residents of poor urban settlements, mitigate their cultural, racial and ethnic differences and as a result increase social cohesion in such regions.

Figure 10 indicates that racial, ethnic and cultural differences are not important in the process of creating shared values. "Creating spatial shared values" is a concept which merits further research in creating stronger social cohesion in multiethnic neighborhoods. For example, as it is clear in Figure 11, a mosque with 200-meter distance from the study area is illustrated. This is belonging to Turkish rural immigrant and can form spatial shared values between all group of the region considering religious common believes.

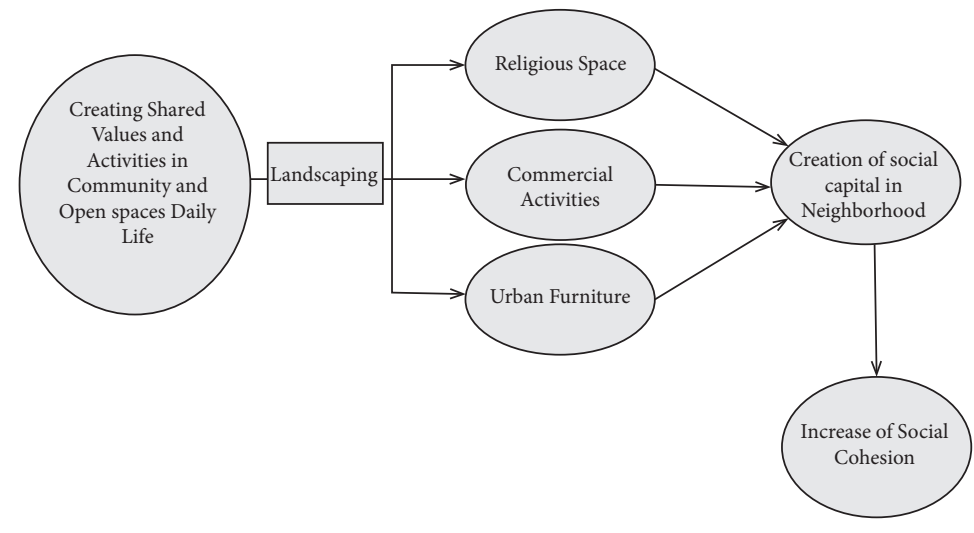

Figure 10. Creating shared values through spatial polices with the purpose of increasing social cohesion

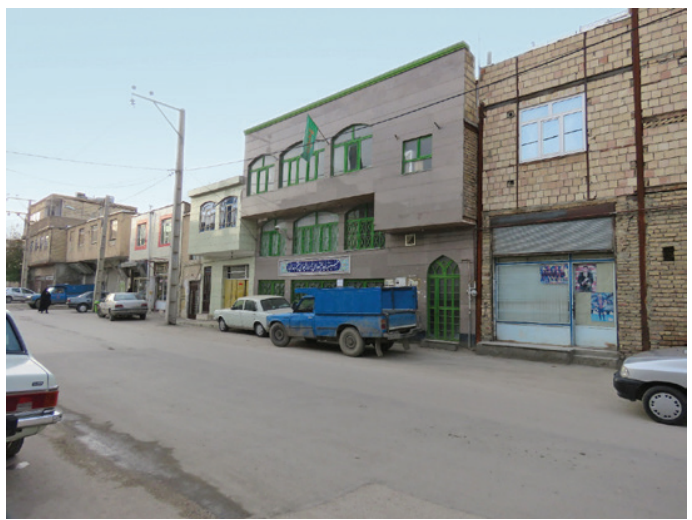

Figure 11. A mosque belonging to Turkish immigrant (Authors, 2018) 


\section{References}

Abramo, P. (2016). Social innovation, reciprocity and the monetarization of territory in informal settlements in Latin American cities. In Social innovation and territorial development (pp. 131-146). Routledge.

Almeida, J., Kawachi, I., Molnar, B. E., \& Subramanian, S. V. (2009). A multilevel analysis of social ties and social cohesion among Latinos and their neighborhoods: results from Chicago. Journal of Urban Health, 86(5), 745-759.

https://doi.org/10.1007/s11524-009-9375-2

Atkinson, R., \& Kintrea, K. (2001). Disentangling area effects: evidence from deprived and non-deprived neighbourhoods. Urban studies, 38(12), 2277-2298.

https://doi.org/10.1080/00420980120087162

Berger-Schmitt, R. (2000). Social cohesion as an aspect of the quality of societies: Concept and measurement. Mannheim: Centre for Survey Research and Methodology (ZUMA) EuReporting Working Paper No.14.

Berkman, L. F., Melchior, M., Chastang, J., Niedhammer, I., Leclerc, A., \& Goldberg, M. (2004). Social integration and mortality: a prospective study of French employers of electricity of France-Gas of France: the GAZEL cohort. American Journal of Epidemiology, 159(2), 167-174. https://doi.org/10.1093/aje/kwh020

Bernard, P. (1999). La Cohésion sociale: Critique d'un quasiconcept. Lien social et Politiques-RIAC, 41, 47-59. https://doi.org/10.7202/005057ar

Black, R., Kniveton, D., \& Schmidt-Verkerk, K. (2013). Migration and climate change: Toward an integrated assessment of sensitivity. In Disentangling migration and climate change (pp. 29-53). Netherlands: Springer. https://doi.org/10.1007/978-94-007-6208-4_2

Black, R., Kniveton, D., Skeldon, R., Coppard, D., Murata, A., \& Schmidt-Verkerk, K. (2008). Demographics and climate change: Future trends and their policy implications for migration. Development Research Centre on Migration, Globalisation and Poverty. Brighton: University of Sussex.

Bolt, G., Van Kempen, R., \& Van Ham, M. (2008). Minority ethnic groups in the Dutch housing market: Spatial segregation, relocation dynamics and housing policy. Urban Studies, 45(7), 1359-1384. https://doi.org/10.1177/0042098008090678

Canadian Policy Research Networks. (1998). Mapping social cohesion [computer File]. Canadian Policy Research Networks.

Carpiano, R. M. (2006). Toward a neighborhood resource-based theory of social capital for health: Can Bourdieu and sociology help?. Social Science \& Medicine, 62(1), 165-175. https://doi.org/10.1016/j.socscimed.2005.05.020

Carpiano, R. M., \& Kimbro, R. T. (2012). Neighborhood social capital, parenting strain, and personal mastery among female primary caregivers of children. Journal of Health and Social Behavior, 53(2), 232-247.

https://doi.org/10.1177/0022146512445899

Chan, J., To, H. P., \& Chan, E. (2006). Reconsidering social cohesion: Developing a definition and analytical framework for empirical research. Social indicators research, 75(2), 273-302. https://doi.org/10.1007/s11205-005-2118-1

Creswell, J. W. (2009). Mapping the field of mixed methods research. Journal of Mixed Methods Research, 3(2), 95-108. https://doi.org/10.1177/1558689808330883

Dickes, P., Valentova, M., \& Borsenberger, M. (2010). Construct validation and application of a common measure of social cohesion in 33 European countries. Social Indicators Research, 98(3), 451-473. https://doi.org/10.1007/s11205-009-9551-5
Doeksen, H. (1997). Reducing crime and the fear of crime by reclaiming New Zealand's suburban street. Landscape and Urban Planning, 39(2), 243-252.

https://doi.org/10.1016/S0169-2046(97)00057-1

Durand-Lasserve, A., \& Royston, L. (2012). Holding their ground: Secure land tenure for the urban poor in developing countries. Earthscan. https://doi.org/10.4324/9781849771566

Durkheim, E. (1984). The division of labor in society. Translator W. D. Halls. New York: The Free Press. https://doi.org/10.1007/978-1-349-17729-5

Echeverría, S., Diez-Roux, A. V., Shea, S., Borrell, L. N., \& Jackson, S. (2008). Associations of neighborhood problems and neighborhood social cohesion with mental health and health behaviors: the Multi-Ethnic Study of Atherosclerosis. Health \& Place, 14(4), 853-865. https://doi.org/10.1016/j.healthplace.2008.01.004

Eger, M. (2010). Even in Sweden: The E_ect of immigration on support for Welfare State Spending. European Sociological Review, 26, 203\{217. https://doi.org/10.1093/esr/jcp017

Egger, S. (2005). Determining a sustainable city model. Environmental Modeling and Software, 21(9), 1235-1246. https://doi.org/10.1016/j.envsoft.2005.04.012

Forrest, R., \& Kearns, A. (2001). Social cohesion, social capital and the neighbourhood. Urban Studies, 38, 2125-2143. https://doi.org/10.1080/00420980120087081

Foster, S., Giles-Corti, B., \& Knuiman, M. (2010). Neighbourhood design and fear of crime: a social-ecological examination of the correlates of residents' fear in new suburban housing developments. Health \& Place, 16(6), 1156-1165. https://doi.org/10.1016/j.healthplace.2010.07.007

Gehl, J. (1996). Life between buildings: Using public space (3rd ed.). Arkitektens Forlag, Copenhagen.

Goulding, Ch. (1999). Grounded Theory: some reflections on paradigm, procedures and misconceptions. University of Wolverhampton.

Hillier, B. (2004). Can streets be made safe?. Urban Design International, 9(1), 31-45. https://doi.org/10.1057/palgrave.udi.9000079

Hataminejad, H., \& Zomorrodian, M. J. (2002). Informal settlement in Mashhad. Shahrdariha, 16(45), 4-16.

Hulse, K., \& Stone, W. (2007). Social cohesion, social capital and social exclusion: A cross cultural comparison. Policy Studies, 28(2), 109-128.

https://doi.org/10.1080/01442870701309049

Jacobs, J. (1961). The death and life of great American cities. New York: Vintage Press.

Jeannotte, M. S. (2003). Singing alone? The contribution of cultural capital to social cohesion and sustainable communities. The International Journal of Cultural Policy, 9(1), 35-49. https://doi.org/10.1080/1028663032000089507

Jen, M. H., Sund, E. R., Johnston, R., \& Jones, K. (2010). Trustful societies, trustful individuals, and health: An analysis of self-rated health and social trust using the World Value Survey. Health \& place, 16(5), 1022-1029.

https://doi.org/10.1016/j.healthplace.2010.06.008

Kahvand, M., Gheitarani, N., Khanian, M. O. J. T. A. B. A., \& Ghadarjani, R. A. Z. I. E. H. (2015). Urban solid waste landfill selection by SDSS. Case study: Hamadan. Environment Protection Engineering, 41(2).

Kawachi, I., \& Berkman, L. F. (2000). Social cohesion, social capital, and health. In L. F. Berkman \& I. Kawachi (Eds.), Social epidemiology (pp. 174-190). New York: Oxford University Press.

Khanian, M., Marshall, N., Zakerhaghighi, K., Salimi, M., \& Naghdi, A. (2018). Transforming agriculture to climate change 
in Famenin County, West Iran through a focus on environmental, economic and social factors. Weather and climate extremes, 21, 52-64. https://doi.org/10.1016/j.wace.2018.05.006

Khanian, M., Bolouhar, B., Gheitarany, N., \& Nezhad, S. M. (2013). Studying the causes of vitality in traditional markets of Iran (Case Study: Shoemaking Order of Central Market of Hamadan). World Applied Sciences Journal, 22(6), 831-835.

Khanian, M., Serpoush, B., \& Gheitarani, N. (2017). Balance between place attachment and migration based on subjective adaptive capacity in response to climate change: the case of Famenin County in Western Iran. Climate and Development, 1-14. https://doi.org/10.1080/17565529.2017.1374238

Khastou, M., \& Rezvani, N. (2010). Effective factors on vitality of urban spaces: Creating a vital urban space relying on the concept of walking shopping center. Hovyate Shahr Journal, 4th year, 6, 113-138.

Kleinhans, R. (2004). Social implications of housing diversification in urban renewal: A review of recent literature. Journal of Housing and the Built Environment, 19(4), 367-390. https://doi.org/10.1007/s10901-004-3041-5

Lalehpour, M., \& Karbasi, P. (2017). Explaining institutional and managerial reasons for the formation of informal settlements in Iran. Amaayesh Mohit, 36(10), 157-191.

Lombard, M. (2014). Constructing ordinary places: Place-making in urban informal settlements in Mexico. Progress in Planning, 94, 1-53. https://doi.org/10.1016/j.progress.2013.05.003

Marzbali, M. H., Abdullah, A., Razak, N. A., \& Tilaki, M. J. M. (2014). Examining social cohesion and victimization in a Malaysian multiethnic neighborhood. International Journal of Law, Crime and Justice, 42(4), 384-405.

https://doi.org/10.1016/j.ijlcj.2014.03.001

Mason, M. J. (2010). Attributing activity space as risky and safe: The social dimension to the meaning of place for urban adolescents. Health \& Place, 16(5), 926-933.

https://doi.org/10.1016/j.healthplace.2010.05.004

Maxwell, J. (1996). Social dimensions of economic growth. Eric John Hanson Memorial Lecture Series, Vol. VIII. University of Alberta.

Mayo, J. M. (1979). Effects of street forms on suburban neighboring behavior. Environment and Behavior, 11(3), 375-397. https://doi.org/10.1177/0013916579113004

Moore, J., \& Pinderhughes, R. (Eds.). (1993). In the Barrios: Latinos and the Underclass Debate: Latinos and the Underclass Debate. Russell Sage Foundation.

Morrison, N. (2003). Neighbourhoods and social cohesion: Experiences from Europe. International Planning Studies, 8(2), 115-138. https://doi.org/10.1080/13563470305154

Naghdi, A., Khanian, M., \& Rueentan, M. (2016). The urban dilemmas in Iran marginal urban area; A case study of Kermanshah city. Journal of Civil Engineering and Urbanism, 1, 16-23.

Nassar, D. M., \& Elsayed, H. G. (2017). From informal settlements to sustainable communities. Alexandria Engineering Journal, 57(4), 2367-2376. https://doi.org/10.1016/j.aej.2017.09.004

O’Connor, P. (1998). Mapping social cohesion [computer File]. Canadian Policy Research Networks.

Osberg, L. (2003). The economic implications of social cohesion (Vol. 16). University of Toronto Press. https://doi.org/10.3138/9781442681149

Patel, V., \& Kleinman, A. (2003). Poverty and common mental disorders in developing countries. Bulletin of the World Health Organization, 81(8), 609-615.

Paumier, C. (2007). Creating a vibrant city center. (ULI) Urban Land Institute, Washington, D Public Land Pub, Washington, DC.
Pearce, N., \& Smith, D. G. (2003). Is social capital the key to inequalities in health?. American Journal of Public Health, 93(1), 122-129. https://doi.org/10.2105/AJPH.93.1.122

Pearl, M., Braveman, P., \& Abrams, B. (2001). The relationship of neighborhood socioeconomic characteristics to Birthweight among 5 ethnic groups in California. American Journal of Public Health, 91(11), 1808-1814. https://doi.org/10.2105/AJPH.91.11.1808

Portes, A. (2014). Downsides of social capital. Proceedings of the National Academy of Sciences, 111(52), 18407-18408. https://doi.org/10.1073/pnas.1421888112

Putnam, R. D. (2000). Bowling alone: America's declining social capital. In Culture and politics (pp. 223-234). New York: Palgrave Macmillan.

Rajulton, F., Ravanera, Z. R., \& Beaujot, R. (2007). Measuring social cohesion: An experiment using the Canadian national survey of giving, volunteering, and participating. Social Indicators Research, 80(3), 461-492.

https://doi.org/10.1007/s11205-006-0011-1

Rosell, S. A. (1995). Changing maps: Governing in a world of rapid change. Carleton University Press, Ottawa.

Ross, C. E., Mirowsky, J., \& Pribesh, S. (2001). Powerlessness and the amplification of threat: Neighborhood disadvantage, disorder, and mistrust. American Sociological Review, 568-591. https://doi.org/10.2307/3088923

Sampson, R. J. (2003). The neighborhood context of well-being. Perspectives in biology and medicine, 46(3), S53-S64. https://doi.org/10.1353/pbm.2003.0059

Sampson, R. J., Morenoff, J. D., \& Gannon-Rowley, T. (2002). Assessing "neighborhood effects": social processes and new directions in research. Annual Review of Sociology, 28, 443478. https://doi.org/10.1146/annurev.soc.28.110601.141114

Shaw, C., \& McKay, H. (1942). Juvenile delinquency and urban areas. University of Chicago Press, Chicago.

Statistical Center of Iran. (2011). General census of population and housing. Retrieved from http:// www.amar.org.ir/Default. aspx?tabid=1160 (In Persian)

Stone, W., \& Hughes, J. (2002). Understanding community strengths. Family Matters, (61), 62.

Strauss, A., \& Corbin, J. (1990). Basics of qualitative research (Vol. 15). Newbury Park, CA: Sage.

Taylor, M. (1998). Combating the social exclusion of housing estates. Housing Studies, 13(6), 819-832. https://doi.org/10.1080/02673039883092

Tunstall, R., \& Lupton, R. (2003). Is targeting deprived areas an effective means to reach poor people? An assessment of one rationale for area-based funding programmes. Centre for Analysis of Social Exclusion, London School of Economics.

UN-Habitat. (2003). The challenge of slums. Global Report on Human Settlements 2003. Earthscan, London.

United Nations. (2004). Scientific Committee on the Effects of Atomic Radiation. Report of the United Nations Scientific Committee on the effects of atomic radiation. United Nations Publications.

UN-HABITAT. (2006). State of the world's Cities 2006/2007. London: Earthscan.

UN-HABITAT. (2008). The State of the world's Cities 2008/2009: Homogenous Cities. Retrieved from www.unhabitat.org

Urban Development and Renewal Company. (2004). Hamadan developing planning. Ministry of Housing and Urbanism.

Van Tran, K. (2015). The value of community cohesion among Vietnamese students in era of urbanisation and globalisation. Social Indicators Research, 1-18. 
Whitley, R., \& McKenzie, K. (2005). Social capital and psychiatry: review of the literature. Harvard review of psychiatry, 13(2), 71-84. https://doi.org/10.1080/10673220590956474

Woolley, F. (1998, October). Social cohesion and voluntary activity: making connections. In CSLS Conference on the State of Living Standards and the Quality of Life in Canada, Ottawa, Ontario (pp. 30-31).

Zakerhaghighi, K., Khanian, M., \& Gheitarani, N. (2015). Subjective quality of life; assessment of residents of informal settlements in Iran (a case study of Hesar Imam Khomeini, Hamedan). Applied Research in Quality of Life, 10(3), 419434. https://doi.org/10.1007/s11482-014-9320-8

Ziegler, E. H. (2007). American cities, urban planning, and place-based crime prevention. The Urban Lawyer, 39, 859. 